\title{
Nuclear-Chemical Synthesis of 1,4-Diazine Quaternary Salts
}

\author{
Nadezhda E. Shchepina ${ }^{1 *}$, Viktor V. Avrorin ${ }^{2}$, Gennadii A. Badun ${ }^{3}$ \\ ${ }^{1}$ Laboratory of Radiochemistry, Natural Sciences Institute of Perm State University, Perm, Russia \\ ${ }^{2}$ Chemistry Department, Saint Petersburg State University, Saint Petersburg, Russia \\ ${ }^{3}$ Radiochemistry Department, M. V. Lomonosov Moscow State University, Moscow, Russia \\ Email: "neshchepina@mail.ru
}

Received December 3, 2012; revised February 2, 2013; accepted February 21, 2013

Copyright (C) 2013 Nadezhda E. Shchepina et al. This is an open access article distributed under the Creative Commons Attribution License, which permits unrestricted use, distribution, and reproduction in any medium, provided the original work is properly cited.

\begin{abstract}
Ion-molecular reactions of nucleogenic phenyl cations with the nucleophilic centers of 1,4-diazines have been investigated for the first time. Previously unknown tritium labeled $N$-phenyl quaternary derivatives of pyrazine and quinoxaline, which are potential radioactive biomarkers, have been obtained by nuclear-chemical method.
\end{abstract}

Keywords: Nucleogenic Phenyl Cations; 1,4-Diazines; Quaternization; Tritium Labeling

\section{Introduction}

Diazines attribute to the six-ring heterocycles with two heteroatoms both of which are nitrogen atoms. Cyclic pyrazine system forms common structural fragment of 1 , 4-diazines. Benzopyrazine or quinoxaline has pyrazine cycle annulated with the benzene ring. 1,4-Diazines and condensed systems with pyrazine ring are known as an important type of heterocyclic derivatives with high biologic activity [1-4]. Synthetic pyrazines exhibit a wide range of physiological activities including antibacterial, antimycobacterial, antiprotozoal and antitumor [5-9]. These promissing results stimulate chemists and biologists for further research in the field of pyrazine derivatives over the last few years [10-22].

Modern progress in biology, biochemistry and molecular genetics along with the experimental medicine is largely determined by the wide application of labeled, especially tritium labeled compounds, for the sensitive direct studies of the biochemical reaction mechanisms and metabolic pathways of the essential pharmaceuticals [23-36].

Owing to this the development of easy and unusual methods for synthesis of new 1,4-diazine derivatives along with tritium labeling becomes an urgent task. Previously we have applied the elaborated nuclear-chemical method based on the consequences of tritium $\beta$-decay for the one-step preparation of unknown and hardly available

"Corresponding author. derivatives of monoazines, effective tritium labeled biological markers [37-41].

\section{Experimental}

\subsection{Tritium Double Labeled Benzene}

Benzene double labeled with tritium was obtained from 1, 4-dibromobenzene (3.4 mg, $0.014 \mathrm{mmol})$, and $\mathrm{n}-\mathrm{Bu}_{3} \mathrm{~N}$ $(5.0 \mu \mathrm{l}, 0.020 \mathrm{mmol})$ in hexane, and tritium gas $(3.3 \mathrm{Ci}$, $0.054 \mathrm{mmol}$ ) by dehalogenation on a $5 \% \mathrm{Pd} / \mathrm{BaSO}_{4}$ catalyst for $1 \mathrm{~h}$ at room temperature [39]. The chemical purity of the synthesized doubly labeled benzene was not less than $99 \%$. Analysis of tritium-labeled benzene was carried out by gas chromatography. The volume specific activity of the obtained solution in hexane was $1 \mathrm{Ci} / \mathrm{ml}$.

\subsection{Nuclear-Chemical Synthesis}

Crystals of the stabilizing salt $\mathrm{KBF}_{4}(\sim 200 \mathrm{mg})$ were placed in $0.5 \mathrm{ml}$ glass ampoules, then $0.055 \mathrm{mmol}$ of substrates: pyrazine $(4.4 \mathrm{mg}$,) or quinoxaline $(7.2 \mathrm{mg})$ dissolved in ether were placed on the salt crystals. The ether was distilled off in vacuum, and after cooling the ampoules with liquid nitrogen, a $\mathrm{C}_{6} \mathrm{H}_{4} \mathrm{~T}_{2}$ hexane solution $(1 \mu \mathrm{l})$ was added. The $\mathrm{C}_{6} \mathrm{H}_{4} \mathrm{~T}_{2}$ concentration was selected so that the ratio of labeled benzene to substrate was not less than 1:1000. The ampoules were sealed, and stored for $1-2$ months at $-15^{\circ} \mathrm{C}$ for accumulation of the nuclear-chemical synthesis products. The ampoules were opened, the contents were transferred to special vials, 
and benzene $(0.5 \mathrm{ml})$ was added, followed by the carrier acetone solution $(0.5 \mathrm{ml}),(1 \mathrm{mg} / \mathrm{ml})$. Due to the absence of isotopic carriers the unlabeled $N$-phenylpyridinium and quinolinium salts $[37,42]$ were used. Unreacted $\mathrm{C}_{6} \mathrm{H}_{4} \mathrm{~T}_{2}$ was removed by distillation in vacuum. Acetone $(0.5 \mathrm{ml})$ was added to the dry residue and samples (about $5 \mu \mathrm{l})$ were taken for isolation of labeled compounds by TLC.

\subsection{TLC Radiochromatography}

Radiochromatography of the obtained tritiated compounds was carried out on glass plates with Analtech TLC Uniplates C18 Reverse Phase silica gel (Fluorescent Indicator) in $\mathrm{MeCN}$. Bands of the chromatographic adsorption layer measuring $0.5 \mathrm{~cm}$ in length were removed into dioxane scintillator and their $\beta$-radioactivity measured with the aid of a Rack Beta (Finland) liquid scintillation counter. Typical radiochromatograms are shown on Figures 1 and 2.

First peaks on the radiochromatograms correspond to the quaternary salts. Relative yields of ion-molecular reactions products were determined as a ratio of the radioactivity of an individual compound towards the sum of all tritium labeled products.

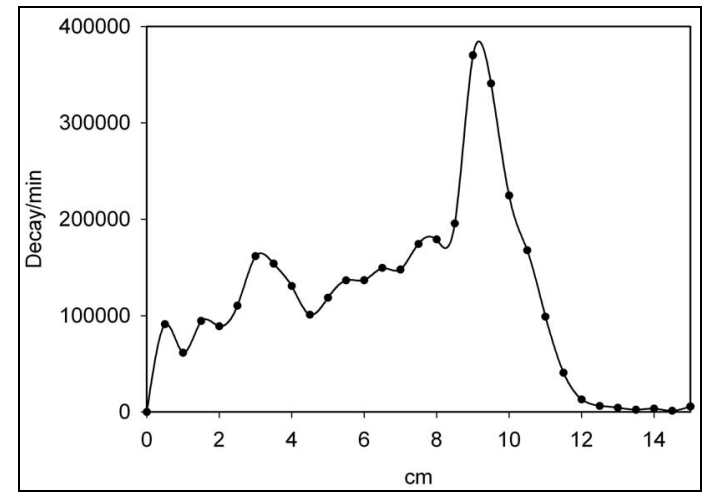

Figure 1. Radiochromatogram of products in the case of $\mathrm{C}_{6} \mathrm{H}_{4} \mathrm{~T}_{2}$-pyrazine-KBF . $_{\text {. }}$

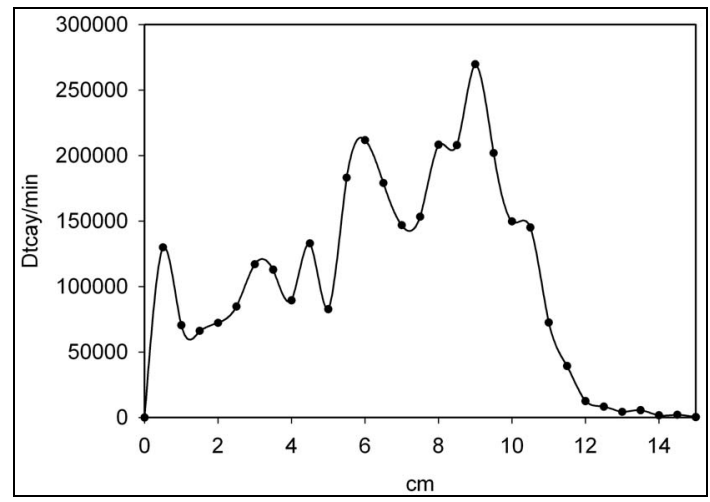

Figure 2. Radiochromatogram of products in the case of $\mathrm{C}_{6} \mathrm{H}_{4} \mathrm{~T}_{2}$-quinoxaline- $\mathrm{KBF}_{4}$.

\section{Results and Discussion}

Generation of nucleogenic phenyl cations (cations formed by radioactive decay) occurs by spontaneous $\beta$-decay of tritium in the labeled benzene. Nuclear-chemical method provides unique opportunity for unusual formation of carbocations along with the several essential advantages: 1) obtained phenyl cations are free, that means without counterion; 2) investigated ion-molecular reactions take place on the surface of stabilizing salt without a solvent; 3 ) all reactions are carried out in the very mild conditions since decay processes are independent from temperature, pressure and so on.

The presence of at least two atoms of tritium in the benzene molecule leads to the preparation of cations labeled with tritium (Scheme 1).

The proposed scheme (Scheme 2) for the ion-molecular interactions of nucleogenic phenyl cations with quinoxaline (for example) may be represented in the following manner.

Upon the interactions of free phenyl cations with the investigated diazines, quaternary salts are formed by $\mathrm{Ad}_{\mathrm{E}}$ (electrophilic addition) as well as substitution products formed by $S_{\mathrm{E}}$ (electrophilic substitution) are produced.

The radiochemical yields of the quaternary salts for the investigated 1,4-diazines are shown in Table 1. Pyrazines have considerable aromatic character; therefore their main reactivity pathways can be predicted by regarding them as pyridines which have a nitrogen atom in the para-position.

Nitrogen atom in azines possesses a pair of electrons, which is not involved in the formation of $\sigma$ or $\pi$ bonding orbitals. Those electrons may form a bond between the

$$
\mathrm{C}_{6} \mathrm{H}_{4} \mathrm{~T}_{2} \stackrel{\beta^{-} \text {-decay }}{\longrightarrow} \mathrm{C}_{6} \mathrm{H}_{4} \mathrm{~T}++{ }^{3} \mathrm{He}
$$

Scheme 1. Generation of nucleogenic phenyl cations.

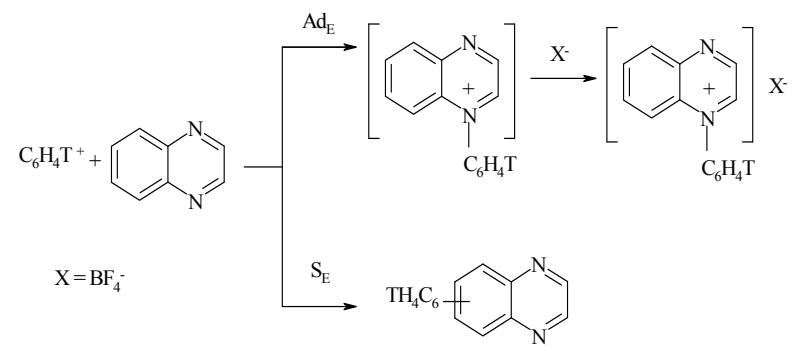

Scheme 2. Pathways of ion-molecular interactions of nucleogenic phenyl cations with quinoxaline.

Table 1. Radiochemical yields of the quaternary salts.

\begin{tabular}{cc}
\hline Substrate & Yield of quaternary salt $\left(\operatorname{Ad}_{\mathrm{E}}\right), \%$ \\
\hline Pyrazine & $4.0 \% \pm 0.5 \%$ \\
Qinoxaline & $6.0 \% \pm 0.5 \%$ \\
\hline
\end{tabular}


nitrogen atom and a carbon atom, which causes the nitrogen atom to become quaternary [43]. Unfortunately only alkyl quaternary derivatives are known for 1,4-diazines. Moreover, $N$-phenyl derivatives of 1,4-diazines haven't been obtained by any methods of classical chemistry yet.

Pyrazine and quinoxaline are weakly basic $\left(\mathrm{pK}_{\mathrm{a}} \sim 0.6\right)$ $[20,21,44]$, therefore the diquaternarization reaction of such derivatives for a long time wasn't available in practice. It was suspected that these failures arise from the expected reduction in nucleophilicity of the second nitrogen attendant upon quaternization of the first. However, the use of more potent trialkyloxonium fluoroborates as alkylating agents led to the formation of several pyrazinium diquats [45]. The success was attributed to the presence of two positive charges in a conjugated ring, which enhanced its reactivity.

It is well-known that most $N$-phenyl quaternary salts of azines are not prepared by direct quaternization but rather the nitrogen substituent is introducing before the ring closure [43]. We have extended our elaborated nuclear-chemical method for the direct phenylation of nitrogen atom in 1,4-diazines. In spite of relatively small radiochemical yields of $N$-phenyl quaternary derivatives of pyrizane and quinoxaline (Table 1) it may be considered as a first step in the new field of previously unknown $\mathrm{N}$-aryl quaternary diazine compounds. Use of free nucleogenic phenyl cations may also lead to the formation of diquaternary derivatives (the second peaks on the radiochromatograms). In the case of quinoxaline (Figure 2), several peaks can be attributed to the products of electrophilic substitution into the benzene ring. This theory is further collaborated by the comparison between quinoxaline and pyrazine diagrams (Figures $\mathbf{1}$ and $\mathbf{2}$ correspondently).

Further research will be undertaken for the detail investigations of ion-molecular interactions of nucleogenic phenyl cations with the nucleophilic centers of 1,4-diazines.

\section{Conclusion}

Elaborated nuclear-chemical method of synthesis enables a new way of the direct nitrogen atom phenylation by the nucleogenic phenyl cations in 1,4-diazines, furnishing previously unknown $N$-phenyl quaternary derivatives.

\section{Acknowledgements}

The authors gratefully acknowledge the financial support of the Russian Foundation for Basic Research (Project No. 10-03-00685a).

\section{REFERENCES}

[1] G. W. H. Cheeseman and E. S. G. Werstiuk, "Recent
Advances in Pyrazine Chemistry," Advances in Heterocyclic Chemistry, Vol. 14, 1972, pp. 99-209. doi:10.1016/S0065-2725(08)60953-8

[2] A. Dell, D. H. Williams, H. R. Morris, G. A. Smith, J. Feeney and G. C. K. Roberts, "Structure Revision of the Antibiotic Echinomycin," Journal of the American Chemical Society Vol. 97, No. 9, 1975, pp. 2497-2502. doi: $10.1021 / \mathrm{ja} 00842 \mathrm{a} 029$

[3] W. Kaim, "The Versatile Chemistry of 1,4-Diazines: Organic, Inorganic and Biochemical Aspects," Angewandte Chemie International Edition, Vol. 22, No. 3, 1983, pp. 171-258. doi:10.1002/anie.198301713

[4] A. F. Pozharskii, A. T. Soldatenkov and A. R. Katritzky, "Heterocycles in Life and Society," 1st Edition, John Wiley \& Sons Ltd., Chichester, 1997.

[5] J. Renault, M. Baron, P. Mailliet, S,Giorgirenault, C. Paoletti and S. Cros, "Heterocyclic Quinones. 2. Quinoxaline-5,6-(and 5-8)-Diones-Potential Antitumoral Agents," European Journal of Medicinal Chemistry, Vol. 16, No. 6, 1981, pp. 545-550.

[6] L. E. Seitz, W. J. Suling and R. C. Reynolds, "Synthesis and Antimycobacterial Activity of Pyrazine and Quinoxaline Derivatives," Journal of Medicinal Chemistry, Vol. 45, No. 25, 2002, pp. 5604-5606. doi:10.1021/jm020310n

[7] A. Jaso, B. Zarranz, I. Aldana and A. Monge, "Synthesis of New Quinoxaline-2-Carboxylate 1,4-Dioxide Derivatives as Anti-Mycobacterium Tuberculosis Agents," Journal of Medicinal Chemistry, Vol. 48, No. 6, 2005, pp. 2019-2025. doi:10.1021/jm049952w

[8] X. Hui, J. Desrivot, C. Bories, P. M. Loiseau, X. Franck, R. Hocquemiller and B. Figadère, "Synthesis and Antiprotozoal Activity of Some New Synthetic Substituted Quinoxalines," Bioorganic \& Medicinal Chemistry Letters, Vol. 16, No. 4, 2006, pp. 815-820. doi:10.1016/j.bmcl.2005.11.025

[9] H. Gao, E. F. Yamasaki, K. K. Chan, L. L. Shen and R. M. Snapka, "DNA Sequence Specificity for Topoisomerase II Poisoning by the Quinoxaline Anticancer Drugs XK469 and CQS," Molecular Pharmacology, Vol. 63, No. 6, 2003, pp. 1382-1388. doi:10.1124/mol.63.6.1382

[10] P. P. Castro, G. Zhao, G. A. Masangkay, C. Hernandez and L. M. Gutierrez-Tunstad, "Quinoxaline Excision: A Novel Approach to Tri- and Diquinoxaline Cavitands," Organic Letters, Vol. 6, No. 10, 2004, pp. 333-336. doi:10.1021/o1036045x

[11] H. Gali-Muhtasib, M. Sidani, F. Geara, A.-D. Mona, J. Al-Hmaira, M. J. Haddadin and G. Zaatari, "Quinoxaline 1,4-Dioxides Are Novel Angiogenesis Inhibitors That Potentiate Antitumor Effects of Ionizing Radiation," International Journal of Oncology, Vol. 24, No. 5, 2004, pp. 1121-1131.

[12] K. R. J. Thomas, M. Velusamy, J. T. Lin, C.-H. Chuen and Y.-T. Tao, "Chromophore-Labeled Quinoxaline Derivatives as Efficient Electroluminescent Materials," Chemistry of Materials, Vol. 17, No. 7, 2005, pp. 1860-1866. doi: $10.1021 / \mathrm{cm} 047705 \mathrm{a}$

[13] J. Ishida, H. Yamamoto, Y. Kido, K. Kamijo, K. Murano, H. Miyake, M. Ohkubo, T. Kinoshita, M. Warizaya, A. Iwashita, K. Mihara, N. Matsuoka and K. Hattori, "Dis- 
covery of Potent and Selective PARP-1 and PARP-2 Inhibitors: SBDD Analysis via a Combination of X-Ray Structural Study and Homology Modeling," Bioorganic \& Medicinal Chemistry, Vol. 14, No. 5, 2006, pp. 13781390. doi:10.1016/i.bmc.2005.09.061

[14] C. Urquiola, D. Gambino, M. Cabrera, M. L. Lavaggi, H. Cerecetto, M. Gonzalez, A. Lopez de Cerain, A. Monge, A. J. Costa-Filho and M. H. Torre, "New Copper-Based Complexes with Quinoxaline N1, N4-Dioxide Derivatives, Potential Antitumoral Agents," Journal of Inorganic Biochemistry, Vol. 102, No. 1, 2008, pp. 119-126. doi:10.1016/i.jinorgbio.2007.07.028

[15] H. A. Shindy and H. A. Soleiman, "Synthesis and Spectral Behaviour of Some Quinoxaline Cyanine Dyes," Canadian Journal on Chemical Engineering \& Technology, Vol. 1, No. 4, 2010, pp. 44-59.

[16] D. P. Singh, S. K. Deivedi, S. R. Hashim and R. G. Singhal, "Synthesis and Antimicrobial Activity of Some New Quinoxaline Derivatives," Pharmaceuticals, Vol. 3, No. 8, 2010, pp. 2416-2425. doi: $10.3390 / \mathrm{ph} 3082416$

[17] R. M. Rajurkar, V. A. Agrawal, S. S. Thonte and R. G. Ingale, "Heterocyclic Chemistry of Quinoxaline and Potential Activities of Quinoxaline Derivatives. A Review," Pharmacophore, Vol. 1, No. 2, 2010, pp. 65-76.

[18] K. Kudo, A. Momotake, Y. Kanna, Y. Nishimura and T. Arai, "Development of a Quinoxaline-Based Fluorescent Probe for Quantitative Estimation of Protein Binding Site Polarity," Chemical Communications, Vol. 47, No. 13, 2011, pp. 3867-3869. doi:10.1039/c1cc10183h

[19] N. C. Kakodkar, R. Peddinti, M. Kletzel, Y. Tian, L. J. Guerrero, S. D. Undevia, D. Gear, A. Chlenski, Q. Yang, H. R. Salwen and S. L. Cohn, "The Quinoxaline AntiTumor Agent (R+)XK469 Inhibits Neuroblastoma Tumor Growth," Pediatric Blood and Cancer, Vol. 56, No. 1, 2011, pp. 164-167. doi:10.1002/pbc.22639

[20] A. K. Patidar, M. Jeyakandan, A. K. Moobiya and G. Selvan, "Exploring Potential of Quinoxaline Moiety," International Journal of PharmTech Research, Vol. 3, No. 1, 2011, pp. 386-392.

[21] S. Noorulla and N. Sreenivasulu, "Antibacterial Activity of Novel Substituted Quinoxaline Heterocycles with Isoniazide," International Journal of Research in Pharmaceutical and Biomedical Sciences, Vol. 2, No. 3, 2011, pp. 1100-1106.

[22] S. Khaksar and F. Rostamnezhad, "A Novel One-Pot Synthesis of Quinoxaline Derivatives in Fluorinated Alcohols," Bulletin of the Korean Chemical Society, Vol. 33, No. 8, 2012, pp. 2581-2584. doi:10.5012/bkcs.2012.33.8.2581

[23] G. V. Sidorov and N. F. Myasoedov, "Synthesis of Tritium-Labelled Biologically Important Diazines," Ruissian Chemical Reviews, Vol. 68, No. 3, 1999, pp. 229-240. doi:10.1070/RC1999v068n03ABEH000471

[24] J. A. Egan, R. P. Nugent and C. N. Filer, "Tritium Labelling and Characterization of the Cognition Enhancing Drug Tacrine Using Several Precursors," Applied Radiation and Isotopes, Vol. 57, No. 6, 2002, pp. 837-840. doi:10.1016/S0969-8043(02)00168-9
[25] J. A. Egan and C. N. Filerga, "Tritium Labeling of the Local Anesthetic Tetracaine via a Polyhalogenated Precursor," Journal of Radioanalytical and Nuclear Chemistry, Vol. 258, No. 1, 2003, pp. 185-187. doi:10.1023/A:1026295101076

[26] D. G. Ahern, A. G. Laseter and C. N. Filer, "Tritium Labelling of Several Potent Fluorinated Antipsychotic Drugs at High Specific Activity," Applied Radiation and Isotopes, Vol. 65, No. 7, 2007, pp. 827-830. doi:10.1016/j.apradiso.2007.02.008

[27] G. Mousseau, Q. Raffy, O. P. Thomas, M. Agez, R. Thai, J. P. Renaul, S. Pin, F. Ochsenbein, J.-C. Cintrat and B. Rousseau, "Footprinting of Protein Interactions by Tritium Labeling," Biochemistry, Vol. 49, No. 20, 2010, pp. 4297-4299. doi:10.1021/bi100031a

[28] G. Heinkele and T. E. Mürdter, "Synthesis of [2H3]Labelled Sulfamethoxazole and Its Main Urinary Metabolites," Journal of Labelled Compounds and Radiopharmaceuticals, Vol. 50, No. 7, 2007, pp. 656-659. doi: $10.1002 / \mathrm{jlcr} .1375$

[29] D. Y. W. Lee, X. S. Ji and X. Zhang, "Synthesis of Tritium-Labeled Puerarin-A Potential Antidipsotropic Agent," Journal of Labelled Compounds and Radiopharmaceuticals, Vol. 50, No. 8, 2007, pp. 702-705. doi: $10.1002 /$ jlcr. 1398

[30] U. Pleiss, "1,4-Dihydropyridines (DHPs) - A Class of Very Potent Drugs: Syntheses of Isotopically Labeled DHP Derivatives during the Last Four Decades," Journal of Labelled Compounds and Radiopharmaceuticals, Vol. 50, No. 9-10, 2007, pp. 818-830. doi:10.1002/jlcr.1418

[31] Y. Hong, S. J. Bonacorsi Jr., Y. Tian, S. Gong, D. Zhang, W. G. Humphreys, B. Balasubramanian, E. H. Cheesman, Z. Zhang, J. F. Castner and P. D. Crane, "Synthesis of [1, 2-3H]Ethylamine Hydrochloride and $\left[{ }^{3} \mathrm{H}\right]$-Labeled Apadenoson for a Human ADME Study," Journal of Labelled Compounds and Radiopharmaceuticals, Vol. 51, No. 2, 2008, pp. 113-117. doi:10.1002/jlcr.1495

[32] W. J. Wheeler and D. K. Clodfelter, "Synthesis of the Tritiated Isotopomers of Enzastaurin and Its N-DesPyridylmethyl Metabolite for Use in ADME Studies," Journal of Labelled Compounds and Radiopharmaceuticals, Vol. 51, No. 4, 2008, pp. 175-181. doi: $10.1002 /$ jlcr. 1497

[33] S.-Y. Wu and M. R. Masjedizadeh, "Synthesis of Tritium Labelled Thiorphan, an Enkephalinase Inhibitor," Journal of Labelled Compounds and Radiopharmaceuticals, Vol. 52, No. 1, 2009, pp. 23-28. doi:10.1002/jlcr.1566

[34] C. Zona and B. La Ferla, "Synthesis of Labeled Curcumin Derivatives as Tools for in Vitro Blood Brain Barrier Trafficking Studies," Journal of Labelled Compounds and Radiopharmaceuticals, Vol. 54, No. 9, 2011, pp. 629-632. doi:10.1002/jlcr.1907

[35] J. Malmquist, A. Bernlind, J Sandell, P Ström and M Waldman, "Tritium Labeling of a $\gamma$-Secretase Inhibitor and Two Modulators as in Vitro Imaging Agents," Journal of Labelled Compounds and Radiopharmaceuticals, Vol. 55, No. 2, 2012, pp. 80-83. doi:10.1002/jlcr.1955

[36] W. J. S. Lockley, A. McEwen and R. Cooke, "Tritium: A Coming of Age for Drug Discovery and Development 
ADME Studies," Journal of Labelled Compounds and Radiopharmaceuticals, Vol. 55, No. 7, 2012, pp. 235-257. doi:10.1002/jlcr.2928

[37] N. E. Shchepina, V. V. Avrorin, G. A. Badun, G. A. Alexandrova, S. E. Ukhanov, V. M. Fedoseev, S. B. Lewis and I. I. Boiko, "Preparation of N-Phenyl-Substituted Quinolinium Derivatives Labeled with Tritium by Chemonuclear Synthesis," Chemistry of Heterocyclic Compounds, Vol. 45, No. 7, 2009, pp. 796-801. doi:10.1007/s10593-009-0359-7

[38] N. E. Shchepina, V. V. Avrorin, G. A. Badun, V. M. Fedoseev and S. B. Lewis, "New Method for the Synthesis of Difficultly Available Sterically Hindered Tritium-Labeled Pyridinium Derivatives," Chemistry of Heterocyclic Compounds, Vol. 46, No. 5, 2010, pp. 547-552. doi:10.1007/s10593-010-0544-8

[39] N. E. Shchepina, V. V. Avrorin, G. A. Badun, S. B. Lewis and S. E. Ukhanov, "Preparation of Fused NPhenyl-Substituted Pyridinium Derivatives by Direct Phenylation with Nucleogenic Phenyl Cations," Chemistry of Heterocyclic Compounds, Vol. 48, No. 2, 2012, pp. 547-552. doi:10.1007/s10593-012-0990-6

[40] N. E. Shchepina, V. V. Avrorin, G. A. Badun, N. A. Bumagin and S. N. Shurov, "Pathways of Ion-Molecular Interactions of Nucleogenic Phenyl Cations with the Nucleophilic Centers of Picolines," Organic and Medicinal Chemistry Letters, Vol. 2, No. 1, 2012, p. 14. doi:10.1186/2191-2858-2-14

[41] N. E. Shchepina, V. V. Avrorin, G. A. Badun, S. B. Lewis and S. N. Shurov, "New Way of Direct Nitrogen Atom Phenylation in Quinoline Derivatives," ISRN Organic Chemistry, Vol. 2012, 2012, Article ID: 526867, pp. $1-4$.

[42] N. E. Shchepina, V. V. Avrorin, G. A. Badun, S. B. Lewis, V. M. Fedoseev and S. E. Ukhanov, "The Reaction of Direct Phenylation by Nucleogenic Cations as a Method of Synthesis of Unknown or Complicated Tritium Labeled Compounds," Moscow University Chemistry Bulletin, Vol. 64, No. 5, 2009, pp. 244-248. doi:10.3103/S0027131409050034

[43] G. F. Duffin, "The Quaternization of Heterocyclic Compounds," Advances in Heterocyclic Chemistry, Vol. 3, 1964, pp. 1-56. doi:10.1016/S0065-2725(08)60540-1

[44] B. Pilarski and K. OsMialowski, "The Relationship between Electron Densities and the pKa Values in a Series of Methylpyrazines," International Journal of Quantum Chemistry, Vol. 28, No. 2, 1985, pp. 239-244. doi: $10.1002 / q u a .560280207$

[45] T. J. Curphey and K. S. Prasad, "Diquaternary Salts. I. Preparation and Characterization of the Diquaternary Salts of Some Diazines and Diazoles," The Journal of Organic Chemistry, Vol. 37, No. 14. 1972. pp. 2259-2266. doi:10.1021/jo00979a012 